\title{
WOMAN-INITIATED DIVORCE AND FEMINIST FIQH IN INDONESIA: Narrating Male Acts of Nushūz in Marriage
}

\author{
Atun Wardatun ${ }^{1 a}$, Bianca J. Smith ${ }^{2 b}$ \\ 1)Univeritas Islam Negeri (UIN) Mataram, \\ 2)Center for Islamic Culture and Society Universitas Mataram \\ email: a)Atun_Wardatun@uinmataram.ac.id, b)bianca.zakia@gmail.com
}

\begin{abstract}
This article examines the issue of woman-initiated divorce (cerai gugat) for the controversial reason in Indonesian Islam known as $n u s h \bar{u} z$ suami or a husband's disobedience in marriage. In contrast to the Indonesian Compilation of Islamic Law which applies nushüz (disobedience) to wives only, our arguments draw on feminist jurisprudence (figh) to show how nushüz also applies to husbands who do not fulfill marital obligations. A husband's nushüz is overlooked by classical scholars and Indonesian Islamic Law alike, yet when understood in a Qur'anic feminist context, it gives a depth of understanding about women's choice to divorce as part of a wider gender justice process and the 'gendering' of divorce. Based on women's post-divorce narratives about $n u s h \bar{u} z$, we propose a feminist figh understanding of gender equality situated in tawhīd as a concept with the potential to form egalitarian-inspired persons (muslimah reformis) and 'essential' and 'true' justice (keadilan hakiki), through reading religious texts and producing knowledge and policies that include women's experiences and voices along with those of men's (mubādalah).
\end{abstract}

Keywords: divorce, Islamic divorce, gender inequality, feminist fiqh, nushūz, Indonesia

DOI: https://doi.org/10.20414/ujis.v24i2.416

\section{Introduction}

IN INDONESIA, woman-initiated divorce constitutes the majority of all Muslim divorce lawsuits ${ }^{1}$ and the number of cases continues to

${ }^{1}$ Mohamad Abdun Nasir, "Islamic Law and Paradox of Domination and Resistance: Women's Judicial Divorce in Lombok, Indonesia," Asian Journal of Social Science 44, no. 1-2 (January 1, 2016): 78-103. 
increase from year to year $(355,842$ cases in $2019 ; 325,505$ in 2018 ; 30,1861 in 2017; and 289,102 in 2016). ${ }^{2}$ In contemporary sociocultural discourses and in Indonesian Islamic scholarship, the recent trend in the high rate of woman-initiated divorce tends to be seen as a negative implication of ideas about 'gender equality' in society, ${ }^{3}$ while overlooking the role of a husband in neglecting his marital obligations, or what we refer to as nushüz suami. In this article, we explore the under-researched and controversial issue of male nushüz in marriage and its role in Muslim divorce.

Islamic law in Indonesia attributes nush $\bar{z} z$ (disobedience) to a wife only, yet when we expand the definition of nushüz to also include the reference to male behaviour in marriage, it gives a depth of understanding about women's choice to divorce as part of a wider gender justice process. Research shows that womaninitiated divorces, for the most part, take place due to inequalities in the domestic sphere as a result of social change and husbands' inability or unwillingness to adapt to shifting constructs of Islamic masculinity in practice. Such gender inequalities and the discourses/ideologies that shape them, require examination in order to understand the role of $n u s h \bar{u} z$ in domestic life.

By engaging and integrating several Indonesian feminist ideas from Kodir ${ }^{4}$, Mulia ${ }^{5}$ and Rafi'ah ${ }^{6}$ about gender equality rooted in

2 Direktorat Jenderal Badan Peradilan Agama, “Data Perkara Peradilan Agama Tingkat Pertama," accessed December 1, 2020, https://badilag.mahkamahagung.go.id/perkara-diterima-dan-diputus-padatingkat-pertama/data-perkara/perkara-diterima-dan-diputus-pada-tingkatpertama.

${ }^{3}$ Lilik Andaryuni, "Pemahaman Gender dan Tingginya Angka Cerai Gugat di Pengadilan Agama Samarinda," FENOMENA 9, no. 2 (December 1, 2017): 155174; Johar Arifin and Ahmad Mas'ari, "Tingginya Angka Cerai Gugat di Pengadilan Agama Pekanbaru dan Relevansinya dengan Konsep Kesetaraan Gender," Marwah: Jurnal Perempuan, Agama dan Jender 16, no. 2 (December 30, 2017): 141-155; Mazroatus Saadah, "Perempuan dan Perceraian: Kajian tentang Cerai Gugat di Pengadilan Agama Bekasi," Al-Ahwal: Jurnal Hukum Keluarga Islam 11, no. 2 (December 11, 2018): 116-132.

${ }^{4}$ Faqihuddin Abdul Kodir, Qirā'ah Mubādalah: Tafsir Progresif untuk Keadilan Gender dalam Islam (Yogyakarta: IRCiSoD, 2019).

${ }^{5}$ Musdah Mulia, Ensiklopedia Muslima Reformis: Pokok-pokok Pemikiran untuk Reinterpretasi dan Aksi (Jakarta: Dian Rakyat, 2019). 
the Islamic doctrine of Oneness of God, known as tawhī ${ }^{7}{ }^{7}$ and from an analysis of narratives from single mothers, we propose a feminist figh interpretation that identifies male $n u s h \bar{u} z$ as a reality for many married women. Our arguments are formed from a combination of phenomenological and anthropological methods with a feminist figh lens which explores how a 'gendering' of divorce takes place, leading to woman-initiated divorce. We do so by giving women's voices audibility in a textual space that reframes the discussion as feminist rather than male-centric. Research for this article was conducted from 2017 to 2018 using indepth interviews, observations, and focus group discussions with Muslim women from different cultural backgrounds in Indonesia.

\section{Nush $\bar{u} z$ in Feminist Figh and Indonesian Islamic Law}

Neglecting obligation and disobedience in Islamic legal terms is referred to as nushīz. In classical scholarship, nushūz has been applied to women only, despite a Qur'anic reference that also applies it to men (Q.s. al-Nisā [4]: 34 and 128). Indonesian and other Muslim feminist scholars of $f_{i q h}{ }^{8}$ have argued that rather than interpreting $n u s h \bar{u} z$ as solely related to a wife's disobedience, that it in fact refers to a more general form of disobedience to Allah by both women and men, and in the context of a marriage, it carries the meaning of disharmony. Given this, a feminist reading of $n u s h \bar{u} z$ can expand the meaning to include nush $\bar{u} z$ suami (a husband's neglect of spousal obligations and disobedience) in cases where he has failed to uphold the values of peace, love, affection, fairness, justice and mercy which are outlined in the

6 Nur Rafi'ah, Nalar Kritis Muslimah: Refleksi atas Keperempuanan, Kemanusiaan, dan Keislaman (Bandung: Afkarunia, 2020).

${ }^{7}$ For a discussion about tawhid and feminism in Islam, see Asma Barlas, Believing Women in Islam: Unreading Patriarchal Interpretations of the Qur'an (Austin: University of Texas Press, 2002); Amina Wadud, Qur'an and Woman: Rereading the Sacred Text from a Woman's Perspective (Oxford: Oxford University Press, 1999).

8 Tuti Harwati, Atun Wardatun, and Nunung Susfita, Figh an Nisa (Jakarta: Kencana, 2019); Kodir, Qirā'ah Mubādalah, 409-418; Mulia, Ensiklopedia Muslima Reformis, 93; Musawwar, "Problem Nusyuz dan Solusinya menurut Al Qur'an (Sebuah Tafsir Nir Kekerasan dalam Keluarga)," Qawwam: Journal for Gender Mainstreaming 1, no. 1 (2006): 5-28; Ahmad Rofiq, Hukum Islam di Indonesia (Jakarta: Raja Grafindo Persada, 2003), 270-272. 
Qur'an. Yet, in Islamic Law, a wife is not permitted to request divorce for reasons of $n u s h \bar{u} z$, whereas a husband is.

Scholars point out that there is an inconsistency in the Compilation of Islamic Law 1/1991 for matters regarding divorce and nushizz. ${ }^{9}$ In Article 116 of the Compilation, the legal requirements for both a husband and a wife to request divorce are the same: adultery, gambling and alcoholism; leaving for 2 years; sentenced to 5 years' imprisonment; committing violence; suffering from a disability or illness which prevents them from carrying out their duties as husband/wife; and ongoing disputes or shiqāq (Article 19 of PP 19/75), together with two additional requirements stated in Article 116 of the Compilation: breaking a prenuptial agreement ( $t a^{\prime} l \bar{k} k$ talāq) and apostacy.

However, there is an additional reason - that of nushüz-given to a husband to divorce his wife as stated in the Compilation (Article 84, point 1-4). This point states that a wife is considered $n u s h \bar{u} z$ if she does not fulfill her obligations as a housewife. Unfairly, this point does not equally apply to husbands who fail to fulfill their obligations. Therefore, we can see that there is an inconsistency in giving equal rights to women and men in matters of divorce. Nushūz refers to a disobedient wife and carries punishment including withholding of money for self-care and medical expenses, amongst others. Should divorce occur in the case of a wife's disobedience, she is not entitled to get an alimony whatsoever during iddah (the mandatory 3-month waiting period a woman must undergo before remarrying after divorce) or the provision of mut'ah (a one-off post-divorce gift for a divorced woman)..$^{10}$ Such laws are rooted in a normative gender hierarchy that firmly places a husband as a leader with financial authority

9 Rika Saraswati, "Justice and the Identities of Women: The Case of Indonesian Women Victims of Domestic Violence Who Have Access to Family Court," in Forum on Public Policy: A Journal of the Oxford Round Table (Faculty of Law, Humanities and the Arts - Papers (Archive), 2013), 1-21, https://ro.uow.edu.au/lhapapers/743.

${ }^{10}$ Interview with judges at Religious Court of Kota Mataram West Nusa Tenggara, 21 September 2017. 
over his wife. ${ }^{11}$ Clearly, women are marginalized and attributed inferiority in terms of $n u s h \bar{u} z$.

The family law system in Indonesia acknowledges women's right to initiate divorce, both in the Marriage Law 1/1974 which is clarified in the government regulation (PP) 9/1975 and in the Compilation of Islamic Law, with the term cerai gugat, adapted from the classical figh term, khulu'. Khulu' can be enacted at the request of a wife with two or more witnesses in cases where a husband has violated the provisions of the marriage. Khulu' balances the unilateral right of talāq (to repudiate divorce) by a husband.12 In fact, khulu' occurs because of a husband's nushūz which frequently cause ongoing disputes. ${ }^{13}$ Judges frequently use the term shiqāq (continuous disputes) as a legal consideration to grant a divorce initiated by a wife. Shiqāq usually occurs due to the neglect of obligations by a husband, especially that of economic support. ${ }^{14}$ In short, shiqa $q$ is the legal term for a husband's failure to lead his family successfully in accordance with Islamic values and provides grounds for a woman to request a divorce. The law has it that $n u s h \bar{u} z$ cannot be applied to a husband because there is no legal consequence.

Contrary to normative understandings and laws within the Compilation, we situate shiqāq within a broader understanding of $n u s h \bar{u} z$, and drawing on feminist readings of the Qur'an, we argue that a husband's failure to uphold marital obligations is nushuzz.

11 Nasir, "Islamic Law and Paradox of Domination and Resistance"; Abu Rokhmad and Sulistiyono Susilo, "Conceptualizing Authority of The Legalization of Indonesian Women's Rights in Islamic Family Law," JOURNAL OF INDONESIAN ISLAM 11, no. 2 (December 5, 2017): 489-508.

${ }_{12}$ Khoiruddin Nasution, "Women's Rights In The Islamic Family Law Of Indonesia," Jurnal Hukum IUS QUIA IUSTUM 12, no. 28 (2005): 147-159.

${ }^{13}$ Erman, "Nusyûz Isteri dan Suami dalam al-Qurần (Sebuah Pendekatan Tematis)," Marwah: Jurnal Perempuan, Agama dan Jender 9, no. 1 (June 2, 2010): 114 .

14 Mohammad Toha Maimun and Misbahul Arifin Rais, "Fenomena Tingginya Angka Cerai Gugat dan Faktor Penyebabnya: Analisis Reflektif atas Kasus-kasus Perceraian di Madura," Islamuna: Jurnal Studi Islam 5, no. 2 (2018): 157-167; Isnawati Rais, “Tingginya Angka Cerai Gugat (Khulu') di Indonesia: Analisis Kritis terhadap Penyebab dan Alternatif Solusi Mengatasinya," $A L$ 'ADALAH 12, no. 1 (2014): 191-204. 
Some Muslim jurists such as Hamka ${ }^{15}$, Hawwa ${ }^{16}$ and Sabiq ${ }^{17}$ acknowledge the existence of male nush $\bar{u} z$ in marriage and reject the ruling that a wife is not entitled to an alimony due to nushuz. Similarly, some religious court judges, seeing actual cases of a husband's $n u s h \bar{u} z$, often do grant a woman's request for divorce in accordance with Article 116 of the Compilation, yet do not state that it is for reasons of $n u s h \bar{u} z .^{18}$

Muslim scholars have proposed changes to address gender inequalities in the Compilation. Nurfaizah ${ }^{19}$ criticizes the Compilation's dehumanizing of women with its sole reference to a wife's nushüz, despite the Qur'an referring to acts of male nushüz in marriage. She proposes that the Compilation must employ a critical perspective, for example, by accommodating a counter legal draft that acknowledges a husband's nushüz. In addition, contemporary scholars such as Syahrur ${ }^{20}$ propose arbitration as a solution, and Jasser Auda $^{21}$ has put forward that the principle 'maqāșìd sharī'a' (to understand God's reason for revealing the law) should be implemented in order to reform the Compilation.

\section{'Gendering' Divorce}

Here we show that processes of 'divorce' and 'divorcing' are gendered, in that 'divorce' is attributed meanings associated with unstable notions about gender and Islamic femininity and masculinity in the Indonesian context. What post-divorce narratives presented here reveal is that women had awareness about gender in terms of wanting to achieve gender equality in their marriages in accordance with Islamic values, yet due to unresolved nushūz they eventually sought to dissolve their

${ }^{15}$ Hamka, Tafsir al Azhar, Juz 5 (Jakarta: Pustaka Panjimas, 1983), 304.

${ }^{16}$ Sa'īd Ḥawwā, Al-Asās fì al-Tafsīr, Juz 2. (Cairo: Dār al-Salām, 1989), 1194.

${ }^{17}$ Sayyid Sābiq, Fiqh al-Sunnah, Juz 2 (Beirut: Dār al-Fikr, 1983), 263.

${ }_{18}$ Interview with judges at Religious Court of Kota Mataram West Nusa Tenggara, 21 September 2017.

${ }^{19}$ Nur Faizah, “Nusyuz: Antara Kekerasan Fisik dan Seksual," Al-Ahwal: Jurnal Hukum Keluarga Islam 6, no. 2 (May 20, 2016): 113-128.

${ }^{20}$ Muhammad Shahrur, Al-Kitāb wa al-Qur'ān: Qirā'ah Mu'āshirah (Cairo: Sina Publisher, 1992).

${ }^{21}$ Jasser Auda, Maqasid Asy-Syari'ah as Philosophy of Islamic Law: A System Approach (London \& Washington: The Institute of Islamic Thought, 2008). 
marriages. It must be pointed out that not all women experiencing the effects of $n u s h \bar{u} z$ are willing to file for divorce due to familial, religious or socio-cultural restrictions. We need to question what kind of 'gender' discourses influence or prevent women from pursuing divorce. A woman's decision to divorce is strongly shaped by the ways in which she is able to interpret her Islamic femininity and situate her piety in Qur'anic values and negotiate this with wider socio-cultural discourses.

Earlier research on Muslim divorce in Java in the 1950s shows there was also a high divorce rate, mostly due to the practice of families arranging forced marriages for their teenage children who would later divorce. ${ }^{22}$ However, data from the 1950s was not gender segregated, and so we do not have access to the number of woman-initiated divorces. In recent academic studies on womaninitiated divorce in Indonesia, however, a woman's awareness of 'gender' is often interpreted as the reason for filing a divorce lawsuit. For example, Lilik Andaryuni argues that awareness of women's rights coupled with economic independence drives wives to file for divorce. ${ }^{23}$ Siregar explains that working women are more likely to file for divorce because they have their own income. ${ }^{24}$ They are usually unwilling to be treated unfairly at home and also have the necessary courage and confidence in comparison to women bound to the household. Therefore, she argues that women's independence is a determining factor in the high divorce rate. By contrast, Ulfa argues that reasons for the

${ }^{22}$ Hildred Geertz, The Javanese Family: A Study of Kinship and Socialization (New York: The Free Press of Glence, Inc, 1961); Daniel S. Lev, Islamic Courts in Indonesia: A Study in the Political Bases of Legal Institutions (Berkeley: University of California Press, 1972); Hisako Nakamura, Conditional Divorce in Indonesia (Cambridge: Islamic Legal Studies Program Harvard law School, 2006); Nina Nurmila, "Social and Religious Constructions of Motherhood in Indonesia: Negotiating Expectations of Childbearing, Family Size and Governmental Policies," in Muslim Mothering: Global Histories, Theories and Practices, ed. M. Aziza Pappano and Dana M. Olwan (Bradford: Demeter Press, 2016), 221-224.

${ }^{23}$ Andaryuni, "Pemahaman Gender," 166.

24 Ully Siregar, "Apakah Independensi Perempuan Berkolerasi Dengan Perceraian?," Deutsche Welle, last modified August 24, 2019, accessed October 1, 2020, https://www.dw.com/id/apakah-independensi-perempuan-berkolerasidengan-perceraian/a-49616886. 
increase in women filing for divorce need to go beyond simply economic access and reach further into looking at the transformative role of gender awareness in women's lives. ${ }^{25}$ However, other studies claim that striving for 'gender equality' is behind the high number of woman-initiated divorces. ${ }^{26}$

Nurlaelawati ${ }^{27}$, furthermore, suggests that the increasing rate of divorce by women in Islamic courts is because the courtroom is the only place where they can get legal protection and access to their right to initiate divorce, unlike men who can repudiate divorce outside the courtroom, which is justified by classical figh. Women who initiate divorce can be said to demonstrate a form of agency that resists the dominant male-centric aspects of figh. ${ }^{28}$

Normative understandings of gender roles that are systematically established through religion and state laws such as the Compilation of Islamic Law 1/1991 and the Indonesian Marriage Law 1/1974 certainly do not encourage husbands to (re)negotiate their masculinity or roles in accordance with household problems they face. There appears to be little understanding that with social change comes an overlapping of gender roles in the family sphere. ${ }^{29}$ Both laws clearly allocate male responsibility to the public and financial spheres, whereas females are placed in charge of all household tasks and the emotional well-being of the entire family. This form of gender order does not adequately represent lived gender practices found throughout the Indonesian

${ }^{25}$ Isnatin Ulfah, "Menggugat Perkawinan: transformasi kesadaran gender Perempuan dan Implikasinya Terhadap Tingginya Gugat Cerai di Ponorogo," Kodifikasia: Jurnal Penelitian Islam 5, no. 1 (December 1, 2010): 1-22.

${ }^{26}$ Arifin and Mas'ari, "Tingginya Angka Cerai Gugat"; Saadah, "Perempuan dan Perceraian."

27 Euis Nurlaelawati, "Muslim Women in Indonesian Religious Courts: Reform, Strategies, and Pronouncement of Divorce," Islamic Law and Society 20, no. 3 (January 1, 2013): 242-271.

${ }^{28}$ Nasir, "Islamic Law and Paradox of Domination and Resistance."

29 Triana Sofiani, "Pergeseran Pola Relasi Gender dan Eskalasi Cerai Gugat dalam Keluarga Perempuan Pekerja Migran," JURNAL PENELITIAN 6, no. 2 (May 21, 2013): 1-14. 
Archipelago $^{30}$ and, rather, should be viewed as open for negotiation ${ }^{31}$.

Given this, dominant constructions of Islamic gender roles in marriages can no longer be expected to consistently reflect traditional constructs due to significant social change. Over the last several decades we have seen these debates demand a new relationship between work and family together with new ideas about sex/gender roles. ${ }^{32}$ Yet, in the Islamic context in Indonesia, studies show that gender roles are still expected to reflect dominant constructs, however, we know that this continues to contribute to a high divorce rate. ${ }^{33}$

Feminist research on women's double-burdens in the postSuharto era indicate that marital problems emerge initially due to unfulfilled household needs and escalate due to wives working outside the home and thus experiencing a multi-burden in public and domestic spheres. ${ }^{34}$ Leading reasons for woman-initiated divorce, therefore, include marital disharmony due to lack of male responsibility, economic problems, and ongoing affairs and arguments. The changes in women's work roles has not necessarily altered husbands' views or understandings about gender and social change, and therefore, many men are unable and unwilling to help lighten their wives' domestic burdens. This indicates an inability to successfully negotiate household issues in response to rapid social change.

Again, these data show that $n u s h \bar{u} z$ is the main reason women file for divorce because a husband lacks in responsibility for treating his wife well both materially and non-materially. As a consequence, we see persistent efforts by husbands to maintain

${ }^{30}$ K. M. Robinson, "Gender Orders in the Indonesian Archipelago," Kultur: The Indonesian Journal for Muslim Cultures 2, no. 2 (2002): 1-20.

31 Atun Wardatun, Negosiasi Ruang: Kritik feminis Liberal Terhadap Persoalan Kontekstual KHI (Mataram: Pusat Studi Wanita IAIN Mataram, 2007).

32 See Diana L. Wolf, Factory Daughters: Gender, Household Dynamics and Rural Industrialization in Java (California: Berkeley University Press, 1992).

33 Yulia Risa, “Tinjauan Yuridis Faktor Penyebab Cerai Gugat Di Pengadilan Agama Kelas II Kota Solok Tahun 2017," Lex Librum: Jurnal Ilmu Hukum 4, no. 2 (2018): 701-713; Saadah, "Perempuan dan Perceraian."

${ }^{34}$ Nurmila, "Social and Religious Constructions." 
and reproduce traditional patriarchal gender discourses and ideologies that place women in the domestic sphere and men in the public sphere as breadwinners and leaders. This doxic gender dynamic has unconditional support in the Compilation (Article 79), and if a wife is classed as disobedient, a husband's marital obligations can be nullified (Article 80 ). ${ }^{35}$

As awareness and understandings about gender issues become more embedded in government institutions, religious spaces, education institutions and the public sphere more generally, there is a greater need to clarify the meanings attached to the term 'gender' in the Islamic context. Together with the very high number of woman-initiated divorces has emerged a predominant popular and (negative) understanding in public life that 'gender equality' is a major reason for the high divorce rate in cases initiated by women. The term 'gender' carries meanings that in popular culture have become stigmatized and associated with women's rights and the LGBT community. 'Gender equality' is therefore often misunderstood as something that encourages women to compete with or out-do men, and this is seen as going against God-given gender roles in Islam, and in turn often prevents women from pursuing divorce for fear of not entering heaven or displeasing Allah.

Along with this understanding is a backlash against women who file for divorce. A female divorcee is often attributed a negative stigma with a range of complex implications in Indonesian society ranging from being viewed as a sexual threat to an undutiful housewife who has failed to uphold harmony in family and society. ${ }^{36}$ These accusatory perceptions class women as those who 'dare' to oppose their husbands, and in doing so,

35 For discussion on gender inequality relating to this law, see John R. Bowen, Islam, Law, Equality In Indonesia: An Anthropology of Public Reasoning (Cambridge: Cambridge University Press, 2003); Wardatun, Negosiasi Ruang.

${ }^{36}$ K. O'Shaughnessy, Gender, State and Social Power in Contemporary Indonesia: Divorce and Marriage Law (London and New York: Routledge, 2009); Bianca J. Smith, "Sexual Desire, Piety, and Law in a Javanese Pesantren: Interpreting Varieties of Secret Divorce and Polygamy," Anthropological Forum 24, no. 3 (July 3, 2014): 227-244. 
destroy family stability and peace. ${ }^{37}$ Such backlash thwarts the achievements and traction women activists have gained in their gender mainstreaming efforts in various aspects of life in Indonesia. ${ }^{38}$ Further, it hinders efforts aimed at positively impacting women's lives at the individual, familial and state levels. In fact, the negative perceptions associated with 'gender equality' have led to hate-based resistance to gender issues and activists working in the gender mainstreaming field.

Popular misconceptions about gender and divorce in Indonesia are due to a lack of education and comprehension of those issues. Negative perceptions about divorce and divorcees are rooted in male-dominated Islamic discourses that place husbands as head and leader above wives in a gender hierarchy in the family and Islamic teachings that state Allah dislikes those who divorce (even though divorce is halal). ${ }^{39}$ These dominant religious constructs, in many cases, play a strong role in deterring women from initiating divorce (Wardatun, forthcoming). Further, as ideal constructs of Islamic femininity do not consistently reflect gendered practices, the same is also the case for ideal constructs of Islamic masculinity; as it is here within this construct that data indicate men feel contronted when practice no longer neatly reflects dominant gender ideology/discourse. We thus see cases where husbands fail to adjust to changing gender roles and ideas in society and the home space as they are confronted with new negotiations of their masculinity, and yet, are lacking in understanding of shifting ideas about gender.

Dominant constructs of Islamic masculinity are therefore challenged when gender roles overlap in domestic space at home

37 Nurhasanah and Rozalinda, "Persepsi Perempuan Terhadap Perceraian: Studi Analisis Terhadap Meningkatnya Angka Gugatan Cerai Di Pengadilan Agama Padang," Kafa ah: Journal of Gender Studies 4, no. 2 (July 12, 2014): 181-201.

38 Ita Musarrofa, "Respons Muslimah Hizbuttahrir Indonesia (MHTI) terhadap Rancangan dan Undang-Undang Terkait Perempuan dan Keluarga," Al-Qalam 21, no. 1 (January 9, 2016): 153-168; Isnatin Ulfah, “Menolak Kesetaraan: Counter-Discourse Dan Motif Politik Di Balik Gagasan Anti Feminisme MHTI," Musãwa Jurnal Studi Gender dan Islam 11, no. 1 (January 29, 2012): 85-114.

${ }^{39}$ In a hadith transmitted by Ibnu 'Umar, it is said that: "the halal act that Allah hates the most is divorce" (Sunan Abu Dawud, No 2180) 
and many men do not have access to alternative discourses that provide them with other models for performing masculinity in the home. It becomes clear, then, that awareness about 'gender equalities' and 'gender inequalities,' together with Islamic teachings on divorce that women strive to uphold in their piety, play roles in interpretations and responses to $n u s h \bar{u} z$, and shape women's choice to either divorce or stay in an unhappy marriage. Our arguments suggest that if nushüz suami is accepted in figh, then women's experiences of divorce would be altered because their unmet needs and suffering would be validated legally and religiously. Stigma towards divorcees would also change and women's burden would lessen because the focus of disharmony would shift to that of the husband, rather than the wife only. In order to address $n u s h \bar{u} z$, there needs to be more comprehensive methods for conflict resolution in families. Below we explore how a combination of feminist figh positions offer pathways for achieving gender balance and family resilience.

\section{Gender Equality in Islam: A Feminist Fiqh Method for Addressing Nush $\bar{u} z$}

Islam provides understandings about gender equality and methods for achieving it utilizing the value of tawhid (the belief in the Oneness and omnipotence of Allah and the foundation of monotheism). Feminists draw on these understandings to assert human equality regardless of any form of difference. ${ }^{40}$ Indonesian feminist Mulia ${ }^{41}$ sees tawhīd as the basis for reformist Muslim women to express humanist values and egalitarianism, while Kodir ${ }^{42}$ considers it to be a concept of liberation so that partnerships and cooperation (mubādalah) between husbands and wives are possible. For Rafi'ah ${ }^{43}$, 'essential' or 'true' justice (keadilan hakiki) can only be sought if it is rooted in a correct understanding of tawhìd that positions God as the ultimate and highest of all.

\footnotetext{
${ }^{40}$ See Barlas, Believing Women in Islam; Wadud, Qur'an and Woman.

${ }^{41}$ Mulia, Ensiklopedia Muslima Reformis.

${ }^{42}$ Kodir, Qirä'ah Mubādalah.

${ }^{43}$ Rafi'ah, Nalar Kritis Muslimah.
} 
These concepts, rooted in tawhīd, form a framework that explains the concept of gender equality in Islam which can be applied in various domains, including in the family. Thus, the kind of gender equality that we formulate and refer to here is shaped by a principle of human equality based on tawhìd as a concept, with the potential to form egalitarian-inspired persons (muslimah reformis) and 'essential' or 'true' justice (keadilan hakiki) through reading religious texts and producing knowledge and policies that include women's experiences and voices along with those of men's (mubādalah).

According to Mulia ${ }^{44}$, 'muslimah reformis' are those who are able to reject all forms of oppression and firmly uphold this position to ensure equality between men and women. Meanwhile, the concept of keadilan hakiki, or 'essential' or 'true' justice, provides a basis for producing knowledge and state policies in order to provide justice and welfare (mașlahah) for all genders. ${ }^{45}$ These two concepts support the emergence of qira'ah mubādalah (reciprocal interpretation method) introduced to Indonesia by the Indonesian male scholar Kodir. ${ }^{46}$ It is, namely, a method for reading the Qur'an, hadith, and figh that places men and women together as equal subjects to whom the aforementioned texts speak. This way of reading aims to reform various misogynistic texts, which often ignore women's experiences in the formation of laws and regulations that relate to women's lives. This method of reading departs from the concern that there are many

${ }^{44}$ Mulia, Ensiklopedia Muslima Reformis.

${ }^{45}$ Rafi' ah, Nalar Kritis Muslimah.

${ }^{46}$ Kodir acknowledges that qirā'ah mubādalah was inspired by the interpretation of classical scholars who emphasized that the verses of the Qur'an are intended for both men and women. In particular, he mentions that the interpretation method of contemporary scholars such as Abu Syuqqah, which links religious texts with the idea of equality and justice, is the basis for the conceptualization of mubādalah. He further acknowledges that inspiration for the birth of mubādalah came from Indonesian thinkers including, Sinta Nuriyah, Ali Yafie, Nasaruddin Umar, Masdar Mas'udi, Musdah Mulia, and Nur Rafi'ah. See Kodir, Qirā'ah Mubādalah, 157-195; Taufan Anggoro, "The Methodology of Contemporary Gender Interpretation: A Study of Qirā'ah Mubādalah," Sawwa: Jurnal Studi Gender 15, no. 1 (April 21, 2020): 53-74. 
interpretations of the very masculine text of the Qur'an, for example, in commandments which literally only address men.

To remedy women's invisibility, a mubādalah reading places women and men as equal subjects who complement each other in a reciprocal partnership. When men and women are situated in this way in the context of family relations, there is an opportunity to reshape the discrimination and marginalization of women and hierarchical power relations in family law. Kodir refers to four areas in relation to family law that urgently require a mubādalah perspective: $n u s h \bar{u} z$, violence, polygamy, and divorce. ${ }^{47}$ The four areas to which Kodir refers are derived from discriminatory attitudes and sexism. Discrimination in the context of family life occurs, for example, by excluding women or men from certain types of work both in public and domestic arenas. While sexism can be considered as not acknowledging the two sexes as a team who can functionally work together, and instead, places them in a hierarchical position shaped by power relations.

Kodir's work has potential to provide gender solutions to problems facing families. When looked at from a mubādalah perspective, both wife and husband are given a choice to adopt a reformist character (transforming themselves) in the face of unavoidable social changes, in order to create a harmonious life and 'essential' or 'true' justice (keadilan hakiki) in the family, as a shared goal. This kind of positioning requires a reshaping of dominant constructs of Islamic masculinity and femininity into a fluid negotiation with changing gender practices.

By using the concept of mubädalah, nushüz can be seen as not solely a wife's offence, but more broadly as encompassing a range of negative actions in a marriage that prevent a husband and wife from living in peace, harmony and love. At its core, a mubādalah reading emphasizes partnership and cooperation between women and men with a conscious aim to work towards a dismantling of hegemonic power relations both in domestic life and social relations. Nushuzz is therefore a reciprocal violation because marital obligations of one party are the rights of the other party.

\footnotetext{
${ }^{47}$ Kodir, Qirā'ah Mubādalah, 408-419.
} 
The following narratives are derived from in-depth interviews and illustrate the struggles of educated career women in negotiating roles, interests, and family goals which after long consideration and inner-conflict, ended in divorce. Divorce is not an easy decision Muslim women make, and in fact, many women choose to live with a husband's $n u s h \bar{u} z$ due to a combination of religious, social and cultural factors, and especially because they choose to put their children's needs first at the expense of their own. ${ }^{48}$

\section{Narrating Nushūz Suami in Practice: Single Mothers and Women's Struggles}

The experiences of women involved in this research suggest that there are conflicting understandings and expectations about gender roles and a lack of adaptation to social change in families. Many informants in Wardatun's fieldnotes ${ }^{49}$ chose to suffer in their marriages, rather than initiate divorce due to the heaviness it would bring them and their children, the stigma from society, and massive changes they would need to undergo in order to start over post-divorce. Therefore, failure to adjust to shifting ideas about gender in many cases has led to husbands practising forms of $n u s h \bar{u} z$, and to wives accepting it.

Masculine attempts to maintain and reproduce Islamic gender norms in the family contribute to marital disharmony when, in fact, gender norms in practice overlap and shift. What the narratives reveal, is that there is quite a large gap in men's knowledge about how to relate in a healthy way with their wives. Qur'anic notions of mother are situated in attributes of love, patience, respect, and loftiness. ${ }^{50}$ Such teachings are very clearly a part of Islam, however, they are not necessarily socialized in depth in Islamic educational curricula or wider Indonesian society.

${ }^{48}$ Wardatun, fieldnotes 2018

${ }^{49}$ Tbid.

${ }^{50}$ M. Aziza Pappano and Dana M. Olwan, "Muslim Mothering: Between Sacred Texts and Contemporary Practices," in Muslim Mothering: Global Histories, Theories and Practices, ed. M. Aziza Pappano and Dana M. Olwan (Bradford: Demeter Press, 2016). 
The narratives show us the dynamics of divorce and how Islamic constructs of femininity and masculinity are negotiated in cases of $n u s h \bar{u} z$, especially for women in terms of prioritizing their motherhood. The informants whose voices we reveal here are those of working women/mothers who chose to pursue divorce in accordance with positive Qur'anic teachings about women and mothers. Three of the informants have a Doctoral degree, two have a Master's degree and only one identifies solely as a housewife who holds a Bachelor's degree. In short, they are mostly educated career women from different geographical regions in Indonesia, including two from Bima, two from Lombok (both are in West Nusatenggara) one from East Java and one from West Java.

While intersectionality certainly does inform women's experiences with divorce and male $n u s h \bar{u} z$, it is also the case that divorce and $n u s h \bar{u} z$ cut through class, social status, age, education, religion and cultural identity. We therefore aim to present women's subjectivities and their experiences with $n u s h \bar{u} z$ in order to demonstrate that $n u s h \bar{u} z$ is a gendered reality for many married women who negotiated at length before deciding to divorce in a society that traditionally stigmatizes women who do so.

\section{Post-Divorce Narratives}

Emotional and financial abuse due to polygamy

Having 3 children, all of whom hold undergraduate degrees, did not deter Lia from divorcing her husband, who is 9 years her junior. She had been considering divorce for 15 years. Lia and her ex-husband are civil servants in a university. Under state law, a civil servant is prohibited from practising polygamy without permission from his first wife. Throughout her marriage, Lia's husband married 3 other women in addition to Lia. He did so illegally, without registering the marriages with the government, which is known as nikah sirri (unregistered, or secret marriage). Lia's husband argued that the Qur'an does not state that a man must obtain his first wife's permission for him to practise polygamy, and therefore, he did not tell her about his other marriages. Lia said that the polygamy started when her children were in primary school. When she first found out about her 
husband's polygamy, she felt destroyed and heart-broken. Yet, she forgave his behavior for the sake of their children.

Finding her husband repeatedly unfaithful with a series of women, she eventually found a way to reconcile her feelings and chose to surrender as long as he was able to manage his responsibilities as a father. Unfortunately, as time went by, and the children were studying at university and needed more financial and emotional support, Lia's husband was not there for them. Her two daughters were in an expensive nursing school, yet Lia's husband was busy taking care of three other women and their children. It was not easy for the two girls to see their father's behavior. The emotional impact on Lia's children was very challenging for Lia, as a mother. When her son was struggling at university, Lia could no longer bear the emotional and financial burdens alone. She reached out to her husband for support, but he only responded with threats of divorce. After 26 years of marriage and polygamy and unfulfilled emotional needs, Lia finally divorced him in order to find peace within herself.

Lia's narrative is familiar to many first wives of polygamous men. Her husband's unwillingness to fulfill his marital obligations on several levels including financial and emotional, describes $n u s h \bar{u} z$ behaviour, yet he felt entitled to act in the way he did based on his masculinity and his perceived rights as a man. While she still has contact with him post-divorce for the sake of the children, she said she has acquired freedom from always thinking about his other women. Lia expressed gratitude for the support she continues to receive from her family and neighborhood after the divorce. Lia's case demonstrates that despite traditional images of female divorcees as sexual threats and failed women, society can, and does support women and children who have experienced abuse.

\section{Not allowed to work and dealing with infertility}

When her husband proposed to her, Fera was undergoing training to become an employee of a well-known Indonesian bank. She decided to resign from her job even though it was her dream job for which she had been preparing for several years. Fera's parents supported her decision based on her fiancé's seriousness 
and his honorary position as a lecturer at a state university. During their first year of marriage, Fera's husband acquired a permanent position at the same university, bringing a sense of financial stability to their home. Fera, however, was under pressure to get pregnant, and despite trying, she was unable to. She began to struggle with domestic life as a housewife and started entertaining the thought of working again. Her husband did not agree to this, as he upheld a particular notion of ideal femininity for his wife, and he wished for her to fulfill it. He needed his wife to see him off to work each day, and welcome him home. This was his request.

Fera negotiated her husband's expectations of her, and at the same time, her inability to get pregnant was a constant burden in her mind, as Indonesian women are culturally expected to achieve status as a mother. Eventually Fera sought medical assistance yet her husband was not willing to do so to check for the possibility of his infertility. Over time, her husband appeared to be busier and busier, and he eventually started micro-managing their finances and limited spending money. One day, Fera found her husband drunk with his friends. She expressed her anger and suggested that alcohol can cause infertility in some men, and that it could possibly be interfering with her inability to conceive. Her husband reacted and an argument ensued. At this time, he started body shaming Fera, saying that she was not as attractive as she previously was. Shortly after the level of emotional abuse had escalated to body shaming, Fera's husband started accusing her of having an affair after finding a text exchange between Fera and her ex-boyfriend in which Fera congratulated him on his plan to marry, while expressing unhappiness in her own marriage.

With this information in hand, Fera's husband demanded the couple divorce. However, as a civil servant at a university, he needed permission from the Vice Chancellor, which is a complicated matter that universities and other government institutions try to avoid. Instead, her husband urged Fera to initiate the divorce because she had no institutional obstacles. Fera at first disagreed, as it was he who wanted to divorce, and rather she pleaded for family mediation to assist in healing her relationship with her husband. Her husband was not convinced, 
and it became clear that he no longer loved Fera. Realizing this, Fera divorced him and resumed work at a private company.

Fera, like many wives, strived hard to uphold an Islamic form of ideal femininity for her husband, yet his lack of awareness of her emotional needs became the source of his nushüz. After some time, Fera accepted her inability to have a baby. After her divorce, she said she feels happy and has found liberation from the painful social pressure women undergo if they are unable to fall pregnant, despite experiencing stigma from her community as being an undutiful and impatient wife. She is focusing on building her online business and buying a new house so she can rebuild her life.

\section{Betrayal}

"I don't want to live in a golden cage", said Risma. "All my needs were met because my husband was a rich entrepreneur. But I was not able to go anywhere, even though I was an activist when I was a university student. When I asked for permission to start up a business to keep me busy and not bored, my husband cheated on me." Sadly, Risma recalled the story of her relationship with the love of her life. He was her friend from university and they were blessed with two intelligent, active sons.

After the children started the final years of high school, Risma wanted to work because she thought her children were independent and self-sufficient enough. She had dedicated seventeen years of domestic life completely to the family. With her husband being busy as a businessman and her children in their own worlds, Risma felt lonely.

She used to be an outstanding student with a multitude of activities in the past. She wanted to work and be useful for others. Unfortunately, her husband didn't understand that. She says she understands his reasoning that he wanted to protect her by her staying at home, but everything changed when she found him with another woman. Risma felt that he had forbidden her from pursuing her interests outside the home in order to isolate her so that she would not discover his betrayal. Two years after the discovery, she filed for divorce, because she felt reassured that her sons would support her decision. 
Risma experienced negative stigma from her family and community who normalized male infidelity. She was questioned as to why she wanted to pursue her interests outside the marriage when all her needs were taken care of by a rich husband. She explained that although others perceived her as a failed wife who should have accepted her husband's infidelity, she was determined to become an even better mother. For her, being a mother is a noble task that is above the role of wife in an unhappy marriage. Like other mothers who chose to divorce, she places a higher value on motherhood rather than being a dutiful wife, and in doing so, expresses an agentive ability to separate the two (wife and mother) which are traditionally intertwined in the family institution.

\section{Mother-in-law versus wife}

Feni and her husband are academics with Doctoral degrees who work at the same university. They appeared to be a happy family, with two sons and a daughter. The news about their divorce shocked their colleagues, yet little did their work mates know that they had been facing ongoing problems in their marriage for a long time. The problems began when they returned from overseas after completing their Doctoral studies. They started arguing about where to live because both of their families wanted them close by. Before leaving to pursue their studies abroad, they had built a house in a village close to Feni's family which happened to be close to the university at which they both teach. Her parents-in-law did not want to accept them residing away from them, and Feni's husband insisted she had to follow his wishes. Her in-laws were persistent in asking them to build a house close to their house which is 30 kilometers from the university and it is a tiring commute every day. The couple agreed to mediation which resulted in them choosing another place away from both sets of parents, in order to be fair. In the end, Feni's husband withdrew from this agreement on the grounds that it is obligatory to follow a mother, and not a wife.

Feni suspects that her husband was deliberately looking for excuses to slander her for being disobedient and daring to fight 
with him. At the time they got married, Feni had a fixed salary and supported the family financially, including financing her husband's education because at that time he had only a temporary job with a small wage. However, her husband claimed that Feni 'oppressed' him. Eventually, Feni divorced him, and during the trial, the issue of oppression remained oblique. What Feni's husband was experiencing fits in with arguments about shifting notions of Islamic masculinity and a husband's inability to adjust when the breadwinner position has moved into a wife's arena and thus gender roles overlap.

The perpetuation of a man's position as head of the family along with the task of providing family income, as regulated by the Indonesian Marriage Law and Compilation of Islamic Law, establishes a dominant construction of Islamic masculinity, which in turn, is socialised into societal gender norms. Legal ideals and social reality, however, do not always coincide. In many cases women are willing to work to earn extra income, and their husbands agree, yet in others, like in Feni's, it demonstrates what can happen when a husband is reluctant to exchange and/or accept gender overlapping in roles. Since her divorce, Feni has experienced stigma, especially at work where she is constantly exposed to bullying and belittling as a ' $j a n d a$ ' (divorcee).

\section{Physical Violence}

Being raised in the pesantren tradition (a traditional Islamic boarding school), Nina entered an arranged marriage. She was still studying in high school at the pesantren when she was called home to be introduced to her future husband who also had an Islamic boarding school background. Her husband is now an academic and Nina chose to become a social worker after completing two Masters degrees. In the 2014 elections, Nina was elected to the legislature and was re-elected in 2019 for a second time. On social media, this couple with their two sons appeared happy with their comfortable life.

Their secret divorce gradually caught on to the media and was quite a shock to their closest friends. Nina, who is always cheerful, successfully hid her feelings. The conflicts within her family had been neatly covered. Psychological conflict and violence had been 
ongoing since the children were very young. The situation climaxed when Nina became a member of the legislature, which had major consequences in the family. For a long time, Nina's husband withheld her monthly maintenance payment (required from husbands in Islamic law) and he had problems with intimacy. What she could not tolerate was when her husband started to beat her at her parents' house. Nina had struggled to maintain her abusive marriage in order to protect her family name, but after the physical violence began, she filed for divorce in order to break free from life with an insecure husband.

Nina is determined to build a new house since her husband claimed their property. In the aftermath of the divorce, she did not expect financial support from her ex-husband, despite winning custody of her youngest son. Her eldest son, who is now at university, chose to live with her. Nina chooses to ignore any form of stigma directed towards her new status as a single mother, and instead is focusing on reconstructing her life with her two sons and working towards peace and happiness.

\section{Verbal Abuse}

Diah met her husband, who was her senior, at university. After graduation they decided to marry. Shortly after falling pregnant with their first child, Diah secured employment as a university lecturer. She had always been a high achiever and after graduating from her Undergraduate degree she pursued a Master's degree which included a year of study in Canada. To further her education, she also acquired a second Master's degree in Australia which in turn led her to pursue a PhD in the USA on a prestigious scholarship. For most of their marriage, Diah was the backbone of the family because she had a permanent job as a university lecturer. After thirteen years of marriage, Diah admitted that she harboured grief because her child often witnessed her father verbally abusing her mother and the little girl was afraid of her father. Her husband also purposely slandered Diah at her university. At this point, Diah initiated divorce. Diah also experienced slander from her parents-in-law who accused her of being a 'rebellious wife'. 
In order to get custody of her child, Diah was willing to leave the family house (which she paid for), and despite experiencing trauma, she has not prevented her daughter from seeing her father. Her ex-husband continues to uphold his parental responsibilities post-divorce, and Diah said she is able to dedicate more time to her academic career after separating from her husband. Like many other divorcees, she continues to receive backlash at her workplace in the form of bullying from colleagues.

The above cases share a common thread; that being the importance placed on their motherhood (except for Fera who did not have children) and providing for their children. We can see from the women's narratives that their lives generally improved after divorce and they felt assured of their piety because they had persevered and struggled for harmony within their marriages for many years before finally choosing a life that supports them rather than one of suffering with male nushüz. Risma, for example, did not feel guilty because she had stayed with her nush $\bar{u} z$ husband while waiting for their children to understand her decision before initiating the divorce. She felt it was acceptable to fail as a wife, but not as a mother. Now she has a new career as a director at a government office. Likewise, Fera, who is still single, chose to pursue an online business rather than working in the public sphere, and has bought a new house on her own. She also financially supports her younger sisters' education, something she believes she would not have been able to do if she was still married.

Meanwhile, problems of domestic violence and infidelity indicate the level of a husband's understanding about how to treat his partner and family in accordance with Qur'anic values of love, respect, honesty, fairness and so on. Domestic violence and cases of adultery are embedded in Islamic representations of masculinity that refer to violence against women, and yet, the post-divorce narratives presented here indicate that when a wife has gained an understanding about gender and requests to be treated well, that the situation worsens.

The multi-burdens women face forms the beginning of prolonged domestic chaos. On the one hand, wives realize that 
their needs are neglected and their rights transgressed. Yet, on the other hand, communication with husbands fails to unite them as a couple in managing change within the family. At this point, it becomes clear that the wife's unilateral gender awareness is the driving factor for initiating divorce. However, a woman does not initiate a divorce without careful and long consideration. Divorcees interviewed for this article explained that prior to divorce, they were frightened of what would follow them postdivorce in terms of being stigmatized in society, yet, after years of suffering and failed attempts at reconciliation with husbands, they do not regret their decision to divorce. Unlike many women who choose to stay in a family defined by male $n u s h \bar{u} z$ for the children's sake, the women here demonstrate how Islam offers women the choice to either stay or leave an abusive husband.

\section{Male Nush $\bar{u} z$ in Marriage: Naming An Unnamed Reality}

While $n u s h \bar{u} z$ takes many forms, we have looked at it in cases of polygamy, shifting gender roles in the family due to work, betrayal, and domestic violence. Of the hundreds of thousands of Muslim women who initiate divorce every year in Indonesia, these cases only represent a minority of voices, yet the stories narrate common themes surrounding nush $\bar{u} z$. The narratives above show that a husband's nushüz is an indisputable reality which is unnamed in Islamic law and the conservative views of patriarchal Ulama'. This article confirms that a husband's nushüz is clearly demonstrated by the high number of wife-initiated divorces which are increasing from year to year. In Ziba Mir Hosseini's view, the tendency to ignore male acts of $n u s h \bar{u} z$ in contemporary Islamic family law is because the law is still included in the category of neo figh. ${ }^{51}$ In the future, it is necessary to attempt to dismantle this figh tradition from within by using the critical reasoning of figh utilizing a reformist feminist point of view or what we have called 'feminist figh' in this article.

51 Ziba Mir-Hosseini, Muslim Family Laws: Dismantling Discriminatory Frameworks from Within, Webinar on Global Conference on Muslim Family Law Reform, 2020, accessed November 24, 2020, https://web.facebook.com/musawahmovement/videos/380268553231551/. 
Ziba $^{52}$ divides figh into several periods relating to Islamic family law. Namely, (1) classical figh which discriminates against women and is not in-line with the spirit of the Qur'an which supports justice for women; (2) 'neo figh' where efforts are made to improve the position of women (for example, during the $20^{\text {th }}$ Century in Muslim countries); and (3) the current and future era of 'feminist reformers' working to dismantle discriminatory laws against women and change figh family law. This last point is what we refer to as 'feminist figh.' From a figh perspective, divorce has implications that present further challenges for women and mothers including not being entitled to post-divorce alimony and the inability to restore the marriage unless they renew their marriage with another 'aqad (talāq $b \bar{a}$ 'in sughrā). Whatever inequalities continue to shape women's experiences of divorce, the religious courts, however, have become places that facilitate escape from the effects of $n u s h \bar{u} z$ in marriage.

If $n u s h \bar{u} z$ is recognized as a legal reality, then the stigma against women who divorce will experience ongoing shifts over time. When judges classify nushüz issues as 'ongoing disputes,' they are reinforcing ideas about women's inferiority by not naming male $n u s h \bar{u} z$. Men cannot gain new skills to rectify their $n u s h \bar{u} z$ if they are not aware of it. In order to achieve this, a balanced understanding about gender equality using feminist ideas including mubādalah, muslimah reformis, keadilan hakiki, and many others not discussed here, is needed for family resilience.

\section{Conclusion}

By engaging Indonesian feminist figh, we have argued that acknowledging male acts of $n u s h \bar{u} z$ in marriage is part of a broader Qur'anic notion of nushūz. We have explored how women's knowledge about gender in/equality, and their ability to make sense of the inequalities they experience in their marriages, influences their decision to file for divorce in a society undergoing changing gender relations. In this context, there is an imbalanced, conflicted gender awareness at play in marriages shaped by

\footnotetext{
${ }^{52}$ Ibid.
} 
Islamic Law, dominant constructions of ideal femininity and masculinity, together with popular discourses on gender.

Engaging feminist figh positions on nushüz with a mubādalah perspective, this article has argued for a shift from a male-centric standpoint on $n u s h \bar{u} z$ to that of a more complex understanding of the role of gender in interpreting divorce cases filed by wives. This article has shown that the high level of divorce is not something that indicates the success of the struggle for gender equality as is commonly understood in the Indonesian popular context. In fact, from the perspective of gender-based family resilience, there is much more work to be done in the area of gender mainstreaming because 'gender equality' is still understood as if it is only a woman's need, without addressing those men who fail to uphold Qur'anic family values. From the perspective of mubādalah, family resilience should be pursued together and gender awareness should benefit all family members, not only husband and wife, but also children as one of the legal consequences of marriage.

The Islamic understanding that gender equality is embedded in tawhìd needs to be instilled not only as a counter to, but also as a replacement for, the discriminatory thinking of classical figh. In this way, teachings about Islam would be rooted in a humanist and transformative perspective. The cultivation of such an understanding is ongoing, starting at the individual level, and then the family sphere, and from there into the public sphere as material for preachers and curricula in Islamic schools. In relation to the issues raised in this article, the state also needs to address inequalities in Family Law in ongoing efforts to eradicate gender injustice.

\section{References}

Andaryuni, Lilik. "Pemahaman Gender dan Tingginya Angka Cerai Gugat di Pengadilan Agama Samarinda." FENOMENA 9, no. 2 (December 1, 2017): 155-174.

Anggoro, Taufan. "The Methodology of Contemporary Gender Interpretation: A Study of Qirā'ah Mubādalah." Sawwa: Jurnal Studi Gender 15, no. 1 (April 21, 2020): 53-74. 
Arifin, Johar, and Ahmad Mas'ari. “Tingginya Angka Cerai Gugat di Pengadilan Agama Pekanbaru dan Relevansinya dengan Konsep Kesetaraan Gender." Marwah: Jurnal Perempuan, Agama dan Jender 16, no. 2 (December 30, 2017): 141-155.

Auda, Jasser. Maqasid Asy-Syari'ah as Philosophy of Islamic Law: A System Approach. London \& Washington: The Institute of Islamic Thought, 2008.

Barlas, Asma. Believing Women in Islam: Unreading Patriarchal Interpretations of the Qur'an. Austin: University of Texas Press, 2002.

Bowen, John R. Islam, Law, Equality In Indonesia: An Anthropology of Public Reasoning. Cambridge: Cambridge University Press, 2003.

Direktorat Jenderal Badan Peradilan Agama. "Data Perkara Peradilan Agama Tingkat Pertama." Accessed December 1, 2020. https://badilag.mahkamahagung.go.id/perkara-diterimadan-diputus-pada-tingkat-pertama/data-perkara/perkaraditerima-dan-diputus-pada-tingkat-pertama.

Erman. "Nusyûz Isteri dan Suami dalam al-Qurần (Sebuah Pendekatan Tematis)." Marwah: Jurnal Perempuan, Agama dan Jender 9, no. 1 (June 2, 2010): 1-14.

Faizah, Nur. "Nusyuz: Antara Kekerasan Fisik dan Seksual." AlAhwal: Jurnal Hukum Keluarga Islam 6, no. 2 (May 20, 2016): 113-128.

Geertz, Hildred. The Javanese Family: A Study of Kinship and Socialization. New York: The Free Press of Glence, Inc, 1961.

Hamka. Tafsir al Azhar. Juz 5. Jakarta: Pustaka Panjimas, 1983.

Harwati, Tuti, Atun Wardatun, and Nunung Susfita. Figh an Nisa. Jakarta: Kencana, 2019.

Ḥawwā, Sa'īd. Al-Asās fì al-Tafsìr. Juz 2. Cairo: Dār al-Salām, 1989.

Kodir, Faqihuddin Abdul. Qirā'ah Mubādalah: Tafsir Progresif untuk Keadilan Gender dalam Islam. Yogyakarta: IRCiSoD, 2019.

Lev, Daniel S. Islamic Courts in Indonesia: A Study in the Political Bases of Legal Institutions. Berkeley: University of California Press, 1972.

Maimun, Mohammad Toha, and Misbahul Arifin Rais. "Fenomena Tingginya Angka Cerai Gugat dan Faktor Penyebabnya: 
Analisis Reflektif atas Kasus-kasus Perceraian di Madura." Islamuna: Jurnal Studi Islam 5, no. 2 (2018): 157-167.

Mir-Hosseini, Ziba. Muslim Family Laws: Dismantling Discriminatory Frameworks from Within. Webinar on Global Conference on Muslim Family Law Reform, 2020. Accessed November 24 , 2020. https://web.facebook.com/musawahmovement/videos/3802685 53231551/.

Mulia, Musdah. Ensiklopedia Muslima Reformis: Pokok-pokok Pemikiran untuk Reinterpretasi dan Aksi. Jakarta: Dian Rakyat, 2019.

Musarrofa, Ita. "Respons Muslimah Hizbuttahrir Indonesia (MHTI) terhadap Rancangan dan Undang-Undang Terkait Perempuan dan Keluarga." Al-Qalam 21, no. 1 (January 9, 2016): 153-168.

Musawwar. "Problem Nusyuz dan Solusinya menurut Al Qur'an (Sebuah Tafsir Nir Kekerasan dalam Keluarga)." Qawwam: Journal for Gender Mainstreaming 1, no. 1 (2006): 5-28.

Nakamura, Hisako. Conditional Divorce in Indonesia. Cambridge: Islamic Legal Studies Program Harvard law School, 2006.

Nasir, Mohamad Abdun. "Islamic Law and Paradox of Domination and Resistance: Women's Judicial Divorce in Lombok, Indonesia." Asian Journal of Social Science 44, no. 1-2 (January 1, 2016): 78-103.

Nasution, Khoiruddin. “Women's Rights In The Islamic Family Law Of Indonesia." Jurnal Hukum IUS QUIA IUSTUM 12, no. 28 (2005): 147-159.

Nurhasanah, and Rozalinda. "Persepsi Perempuan Terhadap Perceraian: Studi Analisis Terhadap Meningkatnya Angka Gugatan Cerai Di Pengadilan Agama Padang." Kafa'ah: Journal of Gender Studies 4, no. 2 (July 12, 2014): 181-201.

Nurlaelawati, Euis. "Muslim Women in Indonesian Religious Courts: Reform, Strategies, and Pronouncement of Divorce." Islamic Law and Society 20, no. 3 (January 1, 2013): 242-271.

Nurmila, Nina. "Social and Religious Constructions of Motherhood in Indonesia: Negotiating Expectations of Childbearing, Family Size and Governmental Policies." In 
Muslim Mothering: Global Histories, Theories and Practices, edited by M. Aziza Pappano and Dana M. Olwan. Bradford: Demeter Press, 2016.

O'Shaughnessy, K. Gender, State and Social Power in Contemporary Indonesia: Divorce and Marriage Law. London and New York: Routledge, 2009.

Pappano, M. Aziza, and Dana M. Olwan. "Muslim Mothering: Between Sacred Texts and Contemporary Practices." In Muslim Mothering: Global Histories, Theories and Practices, edited by M. Aziza Pappano and Dana M. Olwan. Bradford: Demeter Press, 2016.

Rafi'ah, Nur. Nalar Kritis Muslimah: Refleksi atas Keperempuanan, Kemanusiaan, dan Keislaman. Bandung: Afkarunia, 2020.

Rais, Isnawati. “Tingginya Angka Cerai Gugat (Khulu') di Indonesia: Analisis Kritis terhadap Penyebab dan Alternatif Solusi Mengatasinya." AL-'ADALAH 12, no. 1 (2014): 191-204.

Risa, Yulia. “Tinjauan Yuridis Faktor Penyebab Cerai Gugat Di Pengadilan Agama Kelas II Kota Solok Tahun 2017." Lex Librum : Jurnal Ilmu Hukum 4, no. 2 (2018): 701-713.

Robinson, K. M. "Gender Orders in the Indonesian Archipelago." Kultur: The Indonesian Journal for Muslim Cultures 2, no. 2 (2002): 1-20.

Rofiq, Ahmad. Hukum Islam di Indonesia. Jakarta: Raja Grafindo Persada, 2003.

Rokhmad, Abu, and Sulistiyono Susilo. "Conceptualizing Authority of The Legalization of Indonesian Women's Rights in Islamic Family Law." JOURNAL OF INDONESIAN ISLAM 11, no. 2 (December 5, 2017): 489-508.

Saadah, Mazroatus. "Perempuan dan Perceraian: Kajian tentang Cerai Gugat di Pengadilan Agama Bekasi." Al-Ahwal: Jurnal Hukum Keluarga Islam 11, no. 2 (December 11, 2018): 116-132.

Sābiq, Sayyid. Figh al-Sunnah. Juz 2. Beirut: Dār al-Fikr, 1983.

Saraswati, Rika. "Justice and the Identities of Women: The Case of Indonesian Women Victims of Domestic Violence Who Have Access to Family Court." In Forum on Public Policy: A Journal of the Oxford Round Table, 1-21. Faculty of Law, Humanities and the Arts - Papers (Archive), 2013. https://ro.uow.edu.au/lhapapers/743. 
Shahrur, Muhammad. Al-Kitāb wa al-Qur'ān: Qirā'ah Mu'āshirah. Cairo: Sina Publisher, 1992.

Siregar, Ully. "Apakah Independensi Perempuan Berkolerasi Dengan Perceraian?" Deutsche Welle. Last modified August 24, 2019. Accessed October 1, 2020. https://www.dw.com/id/apakah-independensi-perempuanberkolerasi-dengan-perceraian/a-49616886.

Smith, Bianca J. "Sexual Desire, Piety, and Law in a Javanese Pesantren: Interpreting Varieties of Secret Divorce and Polygamy." Anthropological Forum 24, no. 3 (July 3, 2014): 227244.

Sofiani, Triana. "Pergeseran Pola Relasi Gender dan Eskalasi Cerai Gugat dalam Keluarga Perempuan Pekerja Migran." JURNAL PENELITIAN 6, no. 2 (May 21, 2013): 1-14.

Ulfah, Isnatin. "Menggugat Perkawinan: transformasi kesadaran gender Perempuan dan Implikasinya Terhadap Tingginya Gugat Cerai di Ponorogo." Kodifikasia: Jurnal Penelitian Islam 5, no. 1 (December 1, 2010): 1-22.

- - - " "Menolak Kesetaraan: Counter-Discourse Dan Motif Politik Di Balik Gagasan Anti Feminisme MHTI." Musãzwa Jurnal Studi Gender dan Islam 11, no. 1 (January 29, 2012): 85114.

Wadud, Amina. Qur'an and Woman: Rereading the Sacred Text from a Woman's Perspective. Oxford: Oxford University Press, 1999.

Wardatun, Atun. Negosiasi Ruang: Kritik feminis Liberal Terhadap Persoalan Kontekstual KHI. Mataram: Pusat Studi Wanita IAIN Mataram, 2007.

Wolf, Diana L. Factory Daughters: Gender, Household Dynamics and Rural Industrialization in Java. California: Berkeley University Press, 1992. 